\title{
Is it possible to standardize the treatment of primary spontaneous pneumothorax? Part 1: etiology, symptoms, diagnostics, minimally invasive treatment
}

\author{
Wojciech Rokicki ${ }^{1}$, Marek Rokicki ${ }^{1}$, Jacek Wojtacha ${ }^{1}$, Marek Filipowski ${ }^{1}$, Agata Dżejlili ${ }^{2}$ Damian Czyżewski ${ }^{1}$ \\ ${ }^{1}$ Department of Thoracic Surgery in Zabrze, Medical University of Silesia in Katowice, Poland \\ ${ }^{2}$ Department of Surgery, Institute of Tuberculosis and Lung Diseases, Warsaw, Poland
}

Kardiochirurgia i Torakochirurgia Polska 2016; 13 (4): 322-327

\begin{abstract}
The authors of this report present the history of primary spontaneous pneumothorax (PSP) treatment, its etiology, clinical symptoms, and diagnostic methodology. Further, they discuss minimally invasive methods of treating PSP such as thoracentesis and chemical pleurodesis. They discuss the pros and cons of each method, emphasizing that, according to the international recommendations, they should be used as the first line of treatment for PSP.

Key words: primary spontaneous pneumothorax, thoracentesis, chemical pleurodesis.
\end{abstract}

\section{Introduction}

Pneumothorax refers to the presence of air or gases in the pleural cavity. The term was introduced into the medical lexicon by Itard in 1803 and Laennec in 1819 [1]. The term spontaneous pneumothorax was proposed by Kjaergaard in 1932 [2].

Primary spontaneous pneumothorax (PSP) is a global problem; based on various data, its incidence is estimated at 18-28 men/100 000 inhabitants and 1.2-6 women/ 100000 inhabitants [3]. Other publications estimate this incidence at 24 men/100 000 inhabitants and 9.8 women/ 100000 inhabitants [4]. The peak of PSP incidence is observed among young individuals between the ages of 15 and 34 [5].

The most important risk factor for this condition is tobacco addiction. In comparison to non-smokers, the risk is 7 times higher in light smokers (1-12 cig./day), 21 times higher in moderate smokers (13-22 cig./day), and 80 times higher in heavy smokers (> 22 cig./day) [6]. It is perturbing that $80-86 \%$ of young patients after PSP treatment continue to smoke tobacco; as a result, during the first 4 postoperative years, the risk of recurrence is very high and is estimated at approximately 54\% [4]. The fact that familial predisposition increases the risk of developing PSP to $11.5 \%$ has also been underscored [6].

\section{Streszczenie}

Autorzy niniejszego doniesienia przedstawiają historię leczenia samoistnej pierwotnej odmy opłucnowej (SPOO), etiologię jej powstania, objawy kliniczne oraz metodykę diagnostyki. Ponadto omawiają mało inwazyjne metody jej leczenia, takie jak nakłucie i drenaż jamy opłucnej oraz pleurodezę chemiczną. Przedstawiają wady i zalety każdej z tych metod, podkreślając, że zgodnie z międzynarodowymi zaleceniami powinny stanowić pierwszą linię postępowania lekarskiego w leczeniu SPOO. Słowa kluczowe: odma opłucnowa, nakłucie, drenaż, pleurodeza chemiczna.

Another factor considered to cause PSP is inflammatory changes in the ultimate segments of the airway, which can cause pulmonary tissue to rupture when intrapulmonary pressure changes during breathing [7].

The influence of atmospheric pressure on the development of PSP was discussed for a long time in various scientific publications; at present, only rapid changes of atmospheric pressure (e.g., associated with diving, traveling by plane, or violent hurricanes) are considered to contribute to the rupture of already existing blebs or bullae, or pulmonary alveoli affected by inflammation [8]. The most common mechanism of PSP development is the rupture of a subpleural air pocket (a so-called bleb, up to $1 \mathrm{~cm}$ in diameter), located mainly in the apical part of the lung [9].

\section{Primary spontaneous pneumothorax etiology}

The exact cause of PSP development is still largely unknown. During surgical procedures, uni- or bilateral pulmonary blebs and/or emphysematous bullae, located primarily in the apical sections, are found in $>80 \%$ of patients. These lesions, known as emphysema-like changes (ELCS), are located under the visceral pleura and are observed in approximately $79 \%$ in CT scans of patients undergoing surgical treatment. They are considered to form an independent and specific nosological entity $[10,11]$.

Address for correspondence: Prof. Wojciech Rokicki, Department of Thoracic Surgery, Medical University of Silesia, ul. 3 Maja 13-15, 41-800 Zabrze, Poland, phone: +48 509218 583, e-mail: wojtacha@o2.pl

Received: 21.04.2016, accepted: 16.11.2016. 
In 2012, Belchis et al. conducted microscopic studies demonstrating fibroblastic damage of the pulmonary tissue leading to fibrosis of the visceral pleura with islands of fibroblastic foci and myxoid stroma in most PSP patients $[5,12]$. Primary spontaneous pneumothorax development is believed to be caused by ELC rupture, which seems to confirm Vanderschueren's hypothesis concerning the mechanism of pneumothorax development. Although investigations of lung segments from PSP patients conducted with electron microscopy did not demonstrate macro- and microscopic sites of "air leakage", they did demonstrate the presence of diffuse areas of disrupted mesothelial cells of the visceral pleura covered with a layer of inflammatory cells with increased fibrosis and pores 1-20 $\mu \mathrm{m}$ in diameter, suggesting the presence of diffuse pleural porosity $[13,14]$. Hence the return of Stradling and Pole's theory: in 1966, these researchers put forward visceral pleural damage as a cause of PSP. Based on these premises, Cao et al. [15] returned to the previously known method of inducing adhesions by the intrapleural administration of autologous blood. According to these authors, the patient's blood coagulating above the damaged visceral pleura may seal the site of the injury and facilitate its healing.

The view held in recent decades that the presence of air in the pleural cavity is a result of bleb rupture in accordance with the "one-airway-one-bleb-one-leak" rule is overly simplistic as there is a group of PSP patients in whom no blebs were found intraoperatively. Hence the return of an old theory, accepted by most researchers, that the visceral pleura has "pores" through which air may permeate from the lungs into the pleural cavity [16]. It appears that the development of blebs, bullae, and visceral pleural porosity is influenced by a number of incompletely understood factors, the most important of which include: congenital predisposition, peripheral chronic pulmonary parenchymal inflammation (ELCS), anatomic abnormalities of the airway, ischemia of the apical pulmonary segments, malnutrition - low body mass index (BMI), abnormalities in connective tissue structure, cannabis smoking, AIDS, and many other factors that remain unknown $[11,17]$.

According to Haynes and Baumann, the real cause behind rupturing blebs or emphysematous bullae resulting in pneumothorax development has still not been fully explained [11]. Blebs and emphysematous bullae are not the only causes of PSP. Amjadi et al. performed over 250 thoracoscopic sympathectomies due to Raynaud's disease, demonstrating the presence of blebs in approximately $6 \%$ of the patients undergoing surgery. In the analyzed patient group, $46 \%$ were chronic tobacco smokers. The researchers did not remove the blebs during the sympathectomy procedures. Preoperatively, none of the patients disclosed PSP in their medical history, and not even one case of pneumothorax was observed during the 9-year follow-up after the procedure. The authors proposed a hypothesis that blebs are precursors of PSP appearance [18]. These observations seem to be substantiated by the results of thoracoscopic examinations conducted by Noppen and
Dekeukeleire, who believe that the numerous causes of PSP development and recurrence include not only bleb rupture, but also porosity of the visceral pleura [19].

\section{Clinical symptoms and diagnostics}

Detailed physical examination combined with radiological imaging form the basis of PSP diagnostics. Asthenic body build, "shortening" of breath, and sudden chest pain observed in approximately $81 \%$ of patients are the initial and most frequent symptoms of PSP.

The sudden chest pain is believed to result from bleb rupture. This causes air to reach the pleural cavity as the irritant material (bronchial secretion with bacteria) is released from the lungs, which stimulates the development of an inflammatory process in this area. Another rather characteristic symptom is the feeling of moderate dyspnea noted in approximately $39 \%$ of patients. Other notable PSP symptoms include the appearance of persistent cough, necessity of deep breathing, paroxysmal tachycardia, and poor well-being. Therefore, a significant portion of patients is initially examined for cardiovascular diseases [20]. The feeling of dyspnea and breathing difficulties may signify the presence of rare conditions accompanying PSP such as tension pneumothorax (1-5\% of patients) or bilateral pneumothorax (0.5-1.9\% of all patients) [21].

Arterial oxygen saturation is normal in $75-95 \%$ of PSP patients; while breathing indoors, the patients usually exhibit values exceeding 92-94\% [22].

The standard of radiological examinations for PSP according to the British Thoracic Society (BTS) guidelines from 2010 is a chest image in a PA projection taken with the patient standing up. A lateral image of the chest from the side affected by the pneumothorax can also be taken, but it is not required in routine medical practice [23]. At present, computed tomography is the "gold standard" for detecting small pneumothoraces, which allows one to precisely calculate their dimensions. Among the many radiological methods of determining pneumothorax size, of note is the Light index, which consists in measuring the mean dimensions of the lung and the pneumothorax at the level of the hilum and substituting them into the following formula: pneumothorax size $(\%)=100-($ mean lung dimension in $\mathrm{cm} /$ mean pneumothorax dimension in cm) $\times 100$ [24]

Most often, the size is determined in accordance with the guidelines published by the American College of Chest Physicians (ACCP) or the BTS. Americans evaluate the size of pneumothorax based on the distance between the cupula and the apex of the collapsed lung, distinguishing between small $(<3 \mathrm{~cm})$ and large $(>3 \mathrm{~cm})$ pneumothoraces. In turn, British physicians determine the size based on the distance between the chest wall and the side of the collapsed lung measured at the level of the hilum. Like their American counterparts, they classify pneumothorax as small or large. At this point, it should be underscored that in most cases the size of the pneumothorax does not correlate exactly with its clinical symptoms [9] (Fig. 1). 


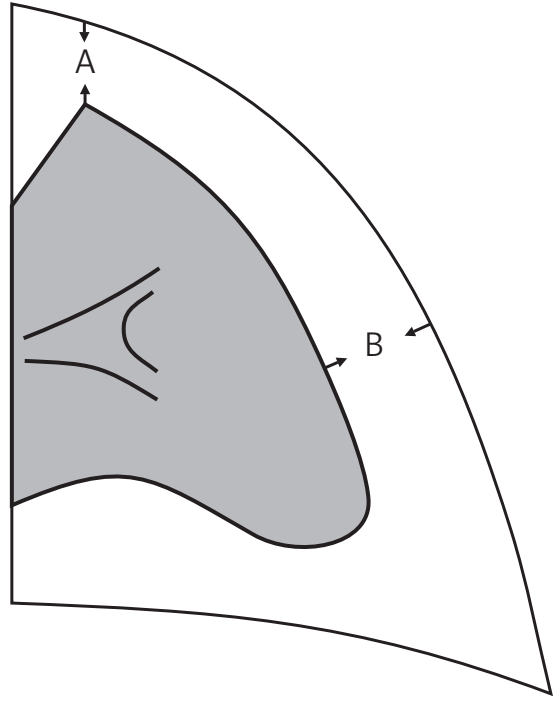

Fig. 1. Assessing pneumothorax size based on chest radiograms. A - The ACCP defines the size of pneumothorax as the distance between the cupula and the apex of the collapsed lung $(<3 \mathrm{~cm}$ : small pneumothorax; $\geq 3 \mathrm{~cm}$ : large pneumothorax). B - The BTS defines the size of pneumothorax as the distance between the chest wall and the side of the collapsed lung measured at the height of the hilum ( $<2 \mathrm{~cm}$ : small; $\geq 3 \mathrm{~cm}$ : large)

Tab. I. Factors influencing the success of PSP treatment with pleural puncture

\begin{tabular}{lc}
\hline Age $<50$ years & $70-81 \%$ success \\
\hline Age $>50$ years & $19-31 \%$ success \\
\hline Pneumothorax volume $<31$ & $89 \%$ success \\
\hline Pneumothorax volume $>31$ & $0 \%$ success \\
\hline Percentage of lung collapse $<50 \%$ & $77 \%$ success \\
\hline Percentage of lung collapse $>50 \%$ & $62 \%$ success \\
\hline
\end{tabular}

In the last decade, ultrasonography has been increasingly used to diagnose PSP; various authors stress that not only is it a minimally invasive method that can be easily repeated, but it is also more sensitive than radiological examinations [25].

\section{Treatment}

At present, there are two key problems to solve with regard to PSP treatment:

- How to stop the air from leaking?

- How to minimize recurrence?

The methods that are currently most frequently used for treating primary spontaneous pneumothorax include

Tab. II. Comparison of the efficacy of pleural puncture and drainage and the associated rates of recurrence after the $1^{\text {st }}$ year

\begin{tabular}{lc} 
Puncture & Drainage \\
\hline $67 \%$ efficacy & $80 \%$ efficacy \\
Recurrence after the $1^{\text {st }}$ year & \\
$16.5 \%$ & $23 \%$ \\
\hline
\end{tabular}

conservative treatment (patient observation), simple puncture of the pleural cavity, intercostal drainage (with a pigtail catheter or a drain), intercostal drainage combined with chemical pleurodesis, thoracoscopy combined with chemical pleurodesis, open thoracotomy with mechanical pleurodesis, video assisted thoracic surgery (VATS) combined with chemical pleurodesis, and open thoracotomy combined with chemical pleurodesis [26, 27].

\section{Conservative treatment}

In cases with small pneumothoraces and scant clinical symptoms, conservative treatment is recommended. The patient's mobility should be limited; they should be placed in bed on the affected side and perform respiratory exercises consisting in overcoming resistance during exhalation. The air from the pleural cavity is spontaneously absorbed at the rate of approximately $2 \% / 24 \mathrm{~h}(50-75 \mathrm{ml}$ $24 \mathrm{~h}$ ), especially when the patient is offered clean oxygen to breathe. It has been suggested that the patient can be discharged home if no symptoms of pneumothorax aggravation are noted after approximately $6 \mathrm{~h}$ of hospital observation (in the Emergency Room), provided that the patient is able to return to the hospital quickly. Approximately $8-15 \%$ of patients qualify for this method of treatment. Its efficacy is estimated at $8-100 \%$, while PSP recurrence is noted in $22-50 \%$ of patients treated with this method [11, 27].

\section{Pleural puncture}

Considering that PSP pathology results from the rupture of subpleural blebs, it appears that this treatment method, enabling the removal of air from the pleural cavity, should be used more often. Frequently, the rupture is so small that the whole lung "contracts" after the puncture, and the air leak is stopped completely. Lung reexpansion (decompression) after puncture is relatively high: $50-83 \%$ according to various publications. It depends on the following factors (Tab. I).

After the puncture, the patient must be monitored for at least $6 \mathrm{~h}$ in the ER $[6,28]$. In randomized controlled trials and a meta-analysis comparing pleural puncture with drainage, statistical analysis revealed no significant differences in the treatment outcomes of these two methods (although the latter was favored) [2, 29]. Another meta-analysis demonstrated that puncture should be the first method of PSP treatment as it significantly shortens the length of hospitalization, thus markedly reducing treatment costs [30]. In turn, randomized trials (5 reports from the years 1994-2012 and 387 analyzed patients) compared the efficacy of puncture vs. drainage with a small drain, reporting the following results (Tab. II).

The intergroup differences presented above were not statistically significant [5, 31].

Based on these data and the guidelines published in the UK (BTS, 2010) and Belgium (Belgian Society of Pneumonology, 2006) recommending pleural puncture as the first step in PSP treatment, it appears that these recom- 
mendations are worth considering in standard medical management [23, 32].

However, not everyone agrees with these guidelines, as a French prospective study from 2014 and American guidelines (ACCP, 2008) showed that treating the first episode of PSP using a small-bore drain with a valve is a good alternative to pleural puncture and/or drainage, reducing the treatment costs significantly [20,33].

\section{Pleural drainage}

This is the next step after puncture if the lung does not expand. Most often, drains with diameters of 10-40 F are used. In the Delphi consensus statement from 2001, researchers from the ACCP recommend performing intercostal drainage in any patient with PSP exceeding $20 \%$ of the pleural cavity volume [34]. From the patient's perspective, intercostal drainage of the pleural cavity is a very painful procedure. Approximately $50 \%$ of patients treated with this method score the pain as 9-10 points on the VAS scale. Additionally, randomized trials demonstrated a number of dangerous complications occurring during chest drainage (internal organ injuries, hemorrhages, infections, and even death) [35].

For several years now, drains of low diameter have been recommended for intercostal drainage of the pleural cavity. It has been demonstrated that these drains are as effective as their larger counterparts, but are associated with a significant reduction in postoperative pain. Moreover, smaller drains are associated with a significant reduction in the length of hospitalization (by 3-4 days on average). These findings have been confirmed by other authors: their retrospective studies demonstrated that $11-13 \mathrm{~F}$ drains are not only better tolerated by the patients, but offer better treatment outcomes than 20-28 F drains [36, 37].

However, there is no clear answer whether suction should be performed in the patients undergoing drainage. The optimal values for the suction force range from 10 to $20 \mathrm{~cm} \mathrm{H}_{2} \mathrm{O}$. Other values are not recommended. It has been demonstrated that the lung expands on its own within 3 days after drainage without suction in $70 \%$ of patients [20]. An expert opinion from the BTS published in 2010 suggests that suction may be beneficial for a small number of patients. So-called "bubbling" combined with no lung expansion persisting for more than $48 \mathrm{~h}$ after the procedure is believed to be an indication for the application of suction.

These observations are confirmed by a Polish report from 2014, which demonstrated a marked benefit of using suction in PSP patients with so-called persistent air-leaks [38].

A retrospective study encompassing 55 patients treated with small-bore drainage connected with a Heimlich valve showed that this method of treating PSP was highly effective [39]. It is believed that drainage with a small-caliber catheter (pigtail catheter, cavafix, neo pneumocath) with a Heimlich valve can be provided as an out-patient treatment even to patients with a large pneumothorax, provid- ed that the patients live near the clinic. These observations are confirmed by a report by Ayed et al.; when a puncture is unsuccessful in a PSP patient, the authors perform drainage with an $8 \mathrm{~F}$ drain with a Heimlich valve and discharge the patient from the ER after $6 \mathrm{~h}$ of observation $[36,39]$.

Researchers from Taiwan published a report in 2014 stating that the first-line gold standard for PSP treatment should be intercostal drainage with a very thin $8 \mathrm{Fr}$ catheter with a Heimlich valve; in the case of recurrence, the second line of treatment should consist in drainage combined with minocycline pleurodesis [40, 41]. In most patients, drainage is used for 2-7 days. In some centers, an air leak persisting for more than 7 days is an indication for surgical treatment [27].

\section{Pleural drainage with chemical pleurodesis}

Chemical pleurodesis is performed to induce adhesions between the pleurae, thus preventing PSP recurrence. Administering an irritant into the pleural cavity results in aseptic pleuritis, causing the pleurae to adhere to each other. The year 1935 saw the first use of talc (hydrated magnesium silicate) as the substance for obliterating the pleural cavity. Since then, it has been used in many centers around the world, and its popularity can be attested by the fact that it is one of the most frequently used substances for obliteration both in Europe and in English-speaking countries around the world (USA, UK, Canada, Australia, New Zealand) [42]. The highest efficacy is associated with talc molecules smaller than $15 \mu \mathrm{m}$.

In clinical practice, the agent is most often provided as 2-4 g of talc with $20 \mathrm{ml}$ of lidocaine in the form of a talc slurry administered through a drain into the pleural cavity [43]. In contrast to previously held views, it has been demonstrated that the use of talc is safe and does not cause acute respiratory distress syndrome [44]. Other substances used intrapleurally to achieve obliteration include bleomycin, dextrose, $50 \%$ glucose, iodine tincture, tetracycline (in the form of a slurry), povidone-iodine, picibanil, silver nitrate, quinacrine, and autologous blood [41]. Over the last few years, most publications have reported tetracyclines, minocycline in particular, to be the agents most frequently used for obliteration. At present, they are recommended as the first line of agents for chemical pleurodesis in PSP patients. Tetracyclines (dosed at $500 \mathrm{mg}$ doxycycline and $7 \mathrm{mg} / \mathrm{kg}$ b.w. minocycline) should be administered intrapleurally in the form of a slurry in $200 \mathrm{mg}(20 \mathrm{ml})$ of lidocaine, which markedly reduces postoperative pain in $10-70 \%$ of patients [23].

A different opinion was presented by Chen et al., who demonstrated that approximately $68 \%$ of patients treated with minocycline experienced pain for up to 6 months after the procedure and required intramuscular injections with pethidine [16]. It was demonstrated that treating PSP with drainage alone is associated with a $23-27 \%$ rate of recurrence, while combining drainage with chemical pleurodesis reduces this rate to approximately $5 \%$. In a randomized trial announced in 2013, Chen et al. proposed the first line of PSP treatment to consist in puncture and/or drainage com- 
Is it possible to standardize the treatment of primary spontaneous pneumothorax? Part 1: etiology, symptoms, diagnostics, minimally invasive treatment

bined with minocycline pleurodesis, which significantly reduces recurrence. Concurrently, they demonstrated that, in contrast to talc, intrapleural minocycline does not change the ventilatory parameters of the lungs $\left(\mathrm{VC}\right.$ or $\left.\mathrm{FEV}_{1}\right)$ in PSP patients after the conclusion of treatment $[16,41]$.

The facts presented in this report prove that despite the 200 years that have passed since the first diagnosis of pneumothorax, the precise cause of the condition remains unknown. According to many researchers, the treatment methods described above should constitute the first line of treatment for PSP.

\section{Disclosure}

\section{Authors report no conflict of interest.}

\section{References}

1. Laennec RTH. Traité du diagnostic des maladies des poumons et du coeur. Tome Second Paris: Brosson et Claudé 1819; 4.

2. Kjćgaard H. Spontaneous pneumothorax in the apparently healthy. Acta Med Scand 1932 (Suppl); 43: 1-159.

3. Ayed A, Al-Din HJ. The results of thoracoscopic surgery for primary spontaneous pmeumothorax. Chest 2000; 118: 235-238.

4. Sahn SA, Heffner JE. Spontaneous pneumothorax. N Engl J Med 2000; 342: 868-874.

5. Tschopp JM, Bintcliffe O, Astoul P, Canalis E, Driesen P, Janssen J, Krasnik M, Maskell M, Van Schil P, Tonia T, Waller DA, Marguette CH, Cardillo G. ERS task force statement: diagnosis and treatment of primary spontaneous pneumothorax. Eur Respir J 2015; 46: 321-335.

6. Kelly AM. Review of management of primary spontaneous pneumothorax is the best evidence clearer 15 years on? Medicine Australasia 2007; 19: 303-308.

7. Ohata M, Suzuki H. Pathogenesis of spontaneous pneumothorax. With special referrence of the ultrastructure of emphysematous bullae. Chest 1980; 77: 771-776.

8. Alifano M, Forti Parri SN, Bonfanti B, Arab WA, Passini A, Boaron M, Roche N Atmospheric pressure influences the risk of pneumothorax: beware of the storm! Chest 2007; 131: 1877-1882.

9. Bintcliffe O, Hallifax RJ, Edey A, Feller-Kapman D, Gory-Lee YC, Marquette CH, Tschopp JM, West D, Rahman NM, Maskell NA. Spontaneous pneumothorax: time to rethink management? Lancet Respir Med 2015; 3: 578-588.

10. Noppen M. Spontaneous pneumothorax: epidemiology, pathophysiology and cause. Eur Respir Rev 2010; 19: 217-219.

11. Haynes D, Baumann MH. Pleural controversy: aetiology of pneumothorax. Respirology 2011; 16: 604-610.

12. Huh U, Kim YD, Cho JS, Hoseok I, Lee JG, Lee JH. The effect of thoracoscopic pleurodesis in primary spontaneous pneumothorax: apical parietal pleurectomy versus pleural abrasion. Korean J Thorac Cardiovasc Surg 2012; 45: 316-319.

13. Pagés PB, Delpy JP, Falcoz PE, Thomas PA, Filaire M, Barthes FLP, Dahan M, Bernard A. Videothoracoscopy versus thoracotomy for the treatment of spontaneous pneumothorax: a propensity score analysis. Ann Thorac Surg 2015; 99: 258-264.

14. Radomsky J, Becker H.P, Hartel WE. Pleuraporositat beim idiopathischen Spontanpneumothorax (Pleural porosity in idiopathic spontaneous pneumothorax). Pneumonologie 1989; 43: 250-253.

15. Cao G, Kang J, Wang F, Wang H. Intrapleural instillation of autologous blood for persistent air leak in spontaneous pneumothorax in patients with advanced chronic obstructive pulmonary disease. Ann Thorac Surg 2012; 93 : 1652-1657.

16. Chen JS, Hsu HH, Huang PM, Kuo SW, Lin MW, Chang CC, Lee JM. Thoracoscopic pleurodesis for primary spontaneous pneumothorax with recurrence risk. A prospective randomized trial. Ann Surg 2012; 255: 440-445.

17. Beshay M, Kaiser H, Niedhardt D, Fishback ME, Roth T. Emphysema and secondary pneumothorax in young adults smoking cannabis. Eur J Cardiothorac Surg 2007; 32: 834-838.

18. Amjadi K, Alvarez GG, Vanderhelst E, Velkeniers B, Lam M, Noppen M. The prevalence of blebs or bullae among young healthy adults: a thoracoscopic investigation. Chest 2007; 132: 1140-1145.
19. Noppen M, Dekeukeleire T. Pneumothorax. Respiration 2008; 76: 121-127.

20. Massongo M, Leroy S, Scherpereel A, Vaniet F, Dhalluin X, Chahine B, Sanfiorenzo C, Genin M, Marquette $\mathrm{CH}$. Outpatient management of primary spontaneous pneumothorax: a prospective study. Eur Respir J 2014; 43: 582-590.

21. Leigh-Smith S, Harris T. Tension pneumothorax: time for a re-think? Emerg Med J 2005; 22: 8-16.

22. Kelly AM, Kerr D, Clooney M. Outcomes of emergency department patients treated for primary spontaneous pneumothorax. Chest 2008; 134: 10331036.

23. Mac Duff A, Arnold A, Harvey J; BTS Pleural Disease Guideline Group. Management of spontaneous pneumothorax: British Thoracic Society pleural disease guideline 2010. Thorax 2010; 65: ii18-ii31.

24. Hoi K, Turchin B, Kelly AM. How accurate is the Light index for estimating pneumothorax size? Austral Radiol 2007; 51: 196-198.

25. Brook OR, Beck-Razi N, Abadi S, Filatov J, Ilivitzki A, Litmanovich D, Gaitini D. Sonographic detection of pneumothorax by radiology residents as part of extended focused assessment with sonography trauma. J Ultrasound Med 2009; 28: 749-755.

26. Tschopp JM, Rami-Porta R, Noppen M, Astoul P. Management of spontaneous pneumothorax state of the art. Eur Respir J 2006; 28: 637-650.

27. Rokicki M, Rokicki W, Sieroń-Rokicka B. O sposobach leczenia samoistnej pierwotnej (idiopatycznej) odmy opłucnowej. Pneumonol Alergol Pol 2005; 73: 202-206.

28. Chan SSS, Lam PKW. Simple aspiration as initial treatment for primary spontaneous pneumothorax: results of 91 consecutive cases. J Emerg Med 2005; 28: 133-138.

29. Kaneda H, Nakano T, Taniguchi Y, Saito T, Konobu T, Saito Y. Three-step management of pneumothorax: time for a re-think on initial management. Interact Cardiovasc Thoracic Surg 2013; 16: 182-192.

30. Devanand A, Koh MS, Ong TH, Low SY, Phua GC, Tan KL, Philip Eng CT, Samuel $M$. Simple aspiration versus chest-tube insertion in the management of primary spontaneous pneumothorax a systemic review. Respir Med 2004; 98: 579-590.

31. Ho KK, Ong ME, Koh MS, Wong E, Raghuram J. A randomized controlled trioal comparing minichest tube and needle aspirationin outpatient management of primary spontaneous pneumothorax. Am J Emerg Med 2011; 29: $1152-1157$.

32. De Leyn P, Lismonde $M$, Ninane $V$, Noppen $M$, Slabbynck $H$, Van Meerhaeghe A, Van Schil P, Vermassen F. Guidelines Belgian Society of Pneumology. Guidelines on the management of spontaneous pneumothorax. Acta Chir Belg 2005; 105: 265-267.

33. Zehtabchi S, Rios CL. Management of emergency department patients with primary spontaneous pneumothorax: needle aspiration or tube thoracostomy? Ann Emerg Med 2008; 51: 91-100.

34. Baumann MH, Strange C, Heffner JE, Light R, Kirby TJ, Klein J, Luketich JD, Panacek EA, Sahn SA; AACP Pneumothorax Consensus Group. Management of spontaneous pneumothorax: an American College of Chest Physicians Delphi consensus statement. Chest 2001; 119: 590-602.

35. Luketich JD, Kiss M, Hershey J, Urso GK, Wilson J, Bookbinder M, Ginsberg R. Chest tube insertion: a prospective evaluation of pain management. Clin J Pain 1998; 14: 152-154.

36. Ayed AK, Chandrasekaran C, Sukumar M. Aspiration versus tube drainage in primary spontaneous pneumothorax: a randomized study. Eur Respir J 2006; 27: 477-482.

37. lepsen UW, Ringbaek T. Small-bore chest tubes seem to perform better than larger tubes in treatment of spontaneous pneumothorax. Dan Med J 2013; 60: A4644.

38. Jablonski S, Brocki M, Wawrzycki M, Smigielski J, Kozakiewicz M. Efficacy assessment of the drainage with permanent airflow measurement in the treatment of pneumothorax with air leak. Thorac Cardiovasc Surg 2014; 62: 509-515.

39. Lai SM, Tee OK. Outpatient treatment of primary spontaneous pneumothorax using a small-bore chest drain with a Heimlich valve: the experience of a Singapore emergency department. Eur J Emerg Med 2012; 19: 400-404.

40. Voisin F, Sohier L, Rochas Y, Kerjouan M, Ricordel C, Belleguic C, Desrues B, Jouneau S. Ambulatory management of large spontaneous pneumothorax with pigtail catheters. Ann Emerg Med 2014; 64: 222-228.

41. Chen JS, Chan WK, Yang PC. Intrapleural minocycline pleurodesis for the treatment of primary spontaneous pneumothorax. Curr Opin Pulm Med 2014; 20: 371-376.

42. Lee YC, Baumann MH, Maskell NA, Waterer GW, Eaton TE, Davies RJ, Heffner JE, Light RW. Pleurodesis practice for malignant pleural effusions in 
five English-speaking countries: survey of pulmonologists. Chest 2003; 124: 2229-2238.

43. Genofre EH, Vargas FS, Aceentio MM, Antonangelo L, Teixeira LR, Marchi E. Talc pleurodesis: evidence of systemic inflammatory response to small size talc particle. Respir Med J 2009; 103: 9-17.
44. Bridevaux PO, Tschopp JM, Cardillo G, Marquette CH, Noppen M, Astoul P, Driesen $P$, Bolliger CT, Froudarakis ME, Janssen JP. Short-term safety of thoracoscopic talc pleurodesis for recurrent primary spontaneous oneumothorax: a prospective European multicentre study. Eur Respir J 2011; 38: 770-773. 